\title{
Consequences of climate change for runoff from Alpine regions
}

\author{
L. N. Braun, M. Weber, M. SGhulz \\ Commission for Glaciology, Bavarian Academy of Sciences, Marstallplatz 8, D-80539 Munich, Germany
}

\begin{abstract}
The water balance of Alpine regions is strongly determined by the storage of water in the form of snow and ice. On the basis of long time series of daily precipitation, air temperature and discharge, the conceptual runoff model HBV3-ETH9 was applied to various basins of the eastern Alps showing a glacierization of $0-80 \%$. Using the results of regional climate modelling under the assumption of doubling of $\mathrm{CO}_{2}$, the meteorological input data files were altered taking into account more frequent hot days and additional convective precipitation events during the summer months, and the consequences of these changes for daily discharge were evaluated. The results show that in regions with insignificant glacierization, runoff reacts primarily to changes in precipitation, and less so to rising summer air temperature. In highly glacierized basins, however, the same scenarios suggest strongly enhanced water yields in an initial phase. Higher flood peaks will result when high melt rates and heavy summer rains coincide. If glacier mass losses continue in the more distant future, the glacierized area will diminish and summer discharge will be gradually reduced, resulting in drastic water shortages in hot, dry summers once the glaciers have disappeared.
\end{abstract}

\section{INTRODUCTION}

Runoff from Alpine regions is the integral response of a wide variety of atmospheric and terrestrial processes over different spatial and temporal scales. When investigating the influences of climatic change on runoff on the basin scale one needs to consider the possible changes on different timescales (Fig. 1). The current weather determines the intensity of rainfall and meltwater production over hours to days. For the period of months to a year the sequence of weather patterns will determine the build-up and melting of the seasonal snow cover, and within several years to decades longterm trends of precipitation and air temperature as integral measures of climate will influence the mass balance and spatial extent of glaciers. The resulting discharge will also be influenced by the hydrological and physiographical characteristics of the given basin. The daily values of runoff over some 20-30 years are shown in Figure 2 for the Klausbach and Rofenache basins (for locations, see Fig. 4), as examples of nivo-pluvial and glacial runoff regimes. It is evident from the wide variety of observed discharge conditions that

(a) a calculated mean seasonal variation ("norm year") does not reflect the true character of discharge due to the unavoidable filtering of the weather patterns. As a result, this primary influence on discharge formation is eliminated.

(b) the consequences of a climatic change for the discharge of Alpine regions can be assessed on the basis of an appropriate "reference year" which contains a complete sequence of weather patterns typical for the climatic reference period. Climatic changes are expressed by concrete changes of daily values of climatic data and not by mean general shifts in air temperature or percentage changes of precipitation, for example.

(c) a modelling approach to calculate discharge must consider the dominant runoff processes and storage changes in a complex topography, yet needs a simplified parameterization to be applicable to real-case basins and over extended periods of time.

With respect to the first two points, the contribution here differs from the methodology generally adopted in similar

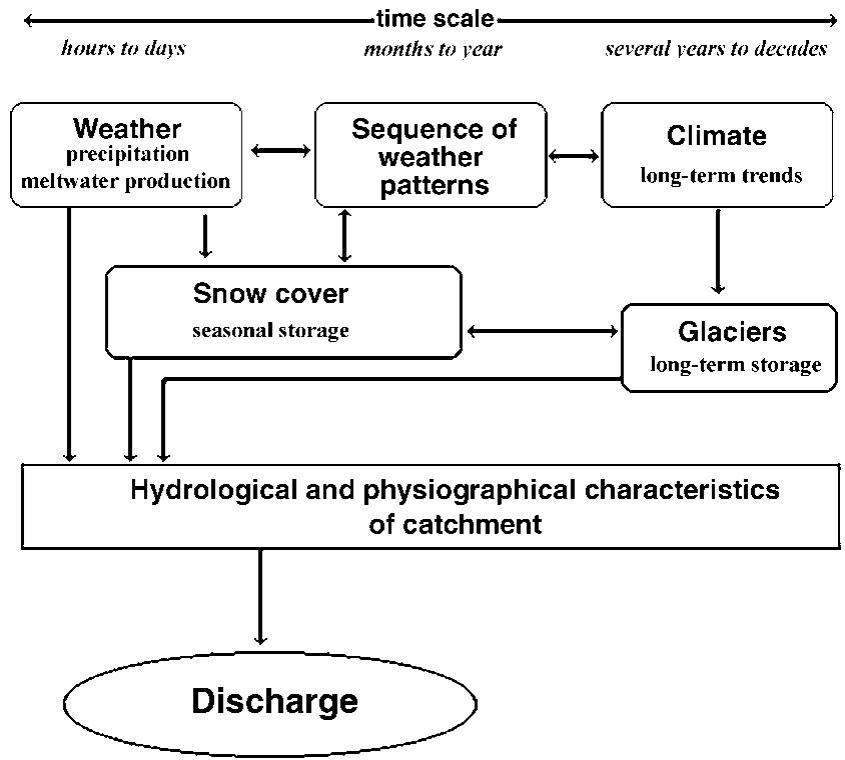

Fig. 1. Schematic diagram showing the main factors of runoff formation in Alpine regions. 
a

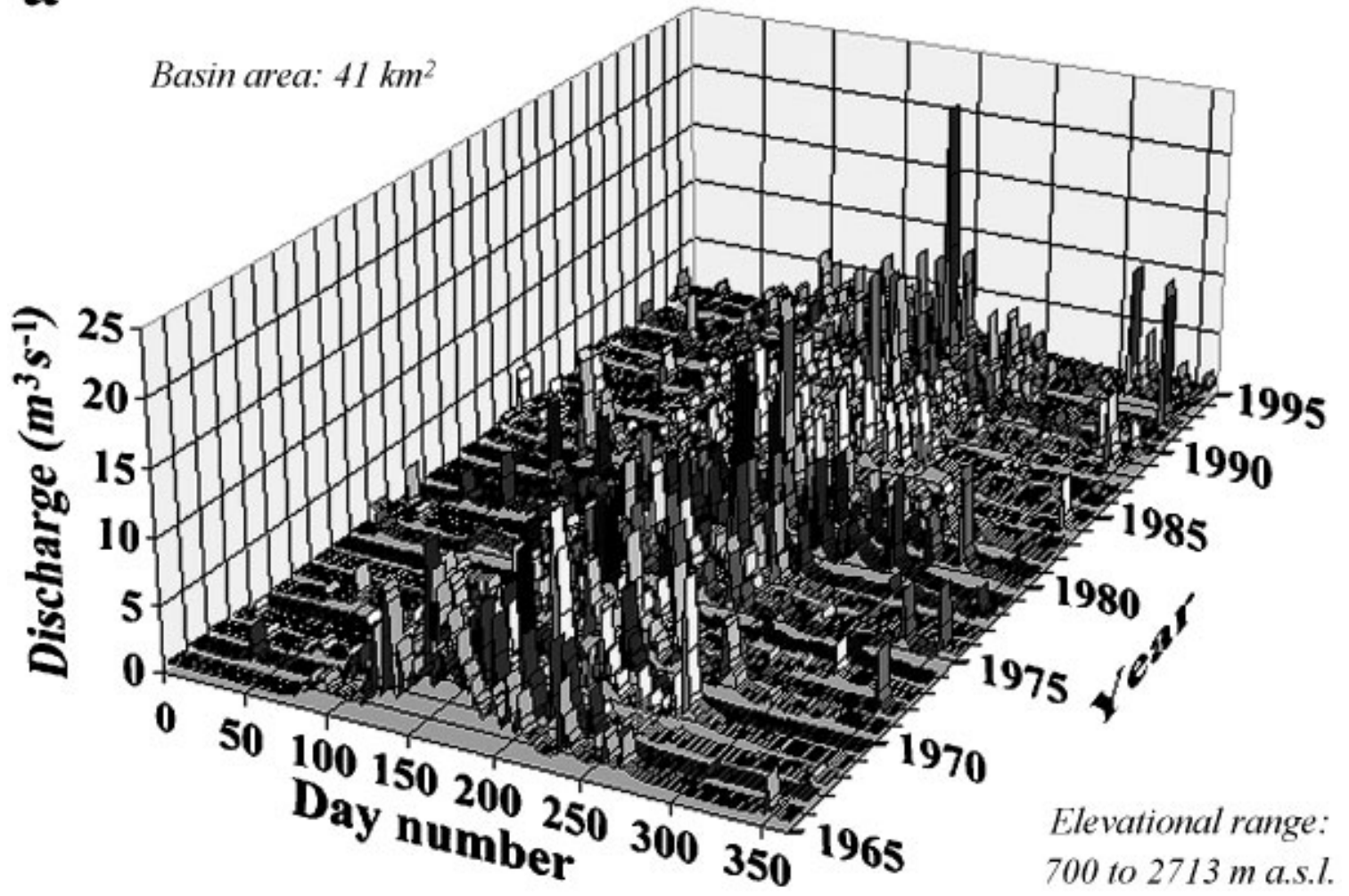

b

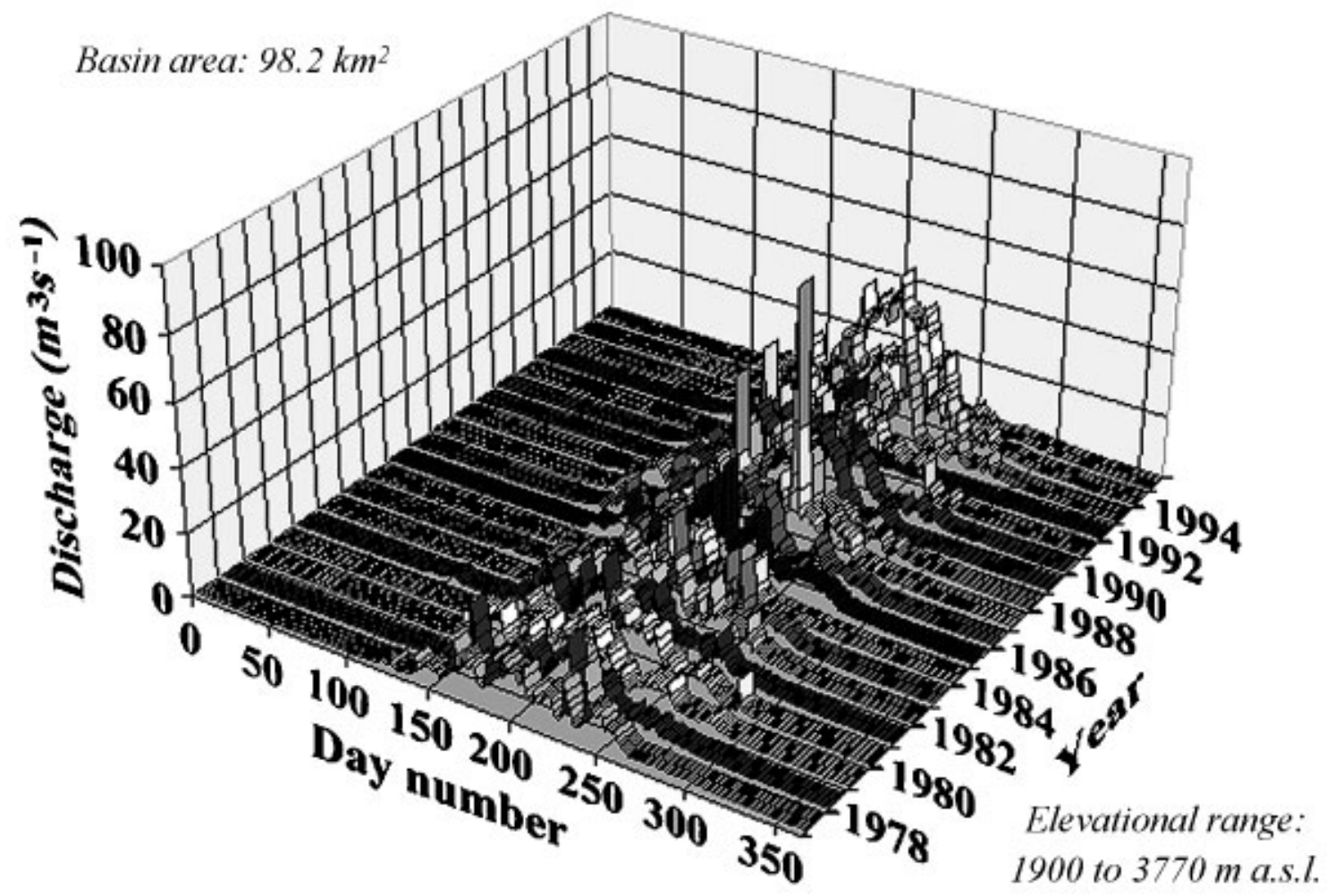

Fig. 2. Examples of the seasonal variation of daily mean discharge in two Alpine basins of differing physiography. (a) Klausbach, Berchtesgadener Alps (no significant glaciation); (b) Rofenache, Oetztal Alps (glaciation 41\%).

studies reported in the literature. For example, general shifts in air temperature (monthly or seasonal means) and percentage changes of precipitation were applied by Kwadijk (1993), Gurtz and others (1997), Ehrler (1998) and Kuhn and Batlogg $(1998,1999)$. The results presented here, however, are based on a study conducted in the framework of a coopera- tive regional climate programme (BayFORKLIM), where Grell and others (1998) and Fuentes and Heimann (2000) evaluated the expected changes in precipitation and air temperature on the regional scale in southern Germany and the eastern Alps under the condition of doubling the $\mathrm{CO}_{2 \mathrm{c}}$ concentration. This paper concentrates on the application of a 


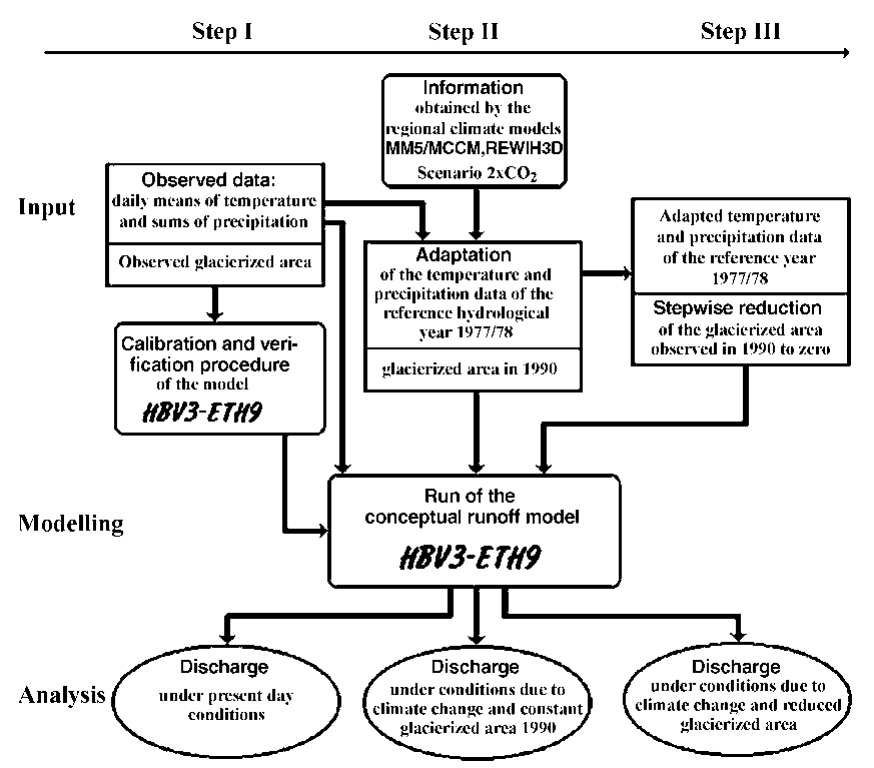

Fig. 3. Overview of the methodological approach in glacierized basins. Step III is omitted in basins without glaciers.

conceptual runoff model which is especially suited to the investigation of hydrological consequences of climatic changes, and full details can be found in Escher-Vetter and others (1998). The applications discussed here can be carried out again by the interested reader using a personal computer program, which is available on CD-ROM as an executable version of the HBV3-ETH9 model and can be ordered from the Commission for Glaciology in Munich.

\section{METHODOLOGY}

Figure 3 gives an overview of the methodological approach used in this study for glacierized basins. In a first step the conceptual runoff model HBV3-ETH9 (Bergström, 1992; Braun and others, 1998) was calibrated and verified in various Alpine basins (Table 1; Fig. 4) using data of many hydrological years to prove its ability to simulate daily discharge under past and present-day hydroclimatological conditions. The generally available daily values of air temperature and precipitation at one representative site of the basin were used as input variables, together with the area-elevation distribution of the basin. If there are glacierized parts within the basin, their corresponding elevational distribution is also required by the model. It can be shown that the model par-

Table 1. Selected physiographic characteristics of the investigated basins

\begin{tabular}{|c|c|c|c|c|}
\hline \multirow[t]{2}{*}{ Basin characteristics } & \multicolumn{3}{|c|}{ Oetztal Alps } & \multirow{2}{*}{$\begin{array}{l}\text { Berchtes- } \\
\text { gaden Alps } \\
\text { Klausbach }\end{array}$} \\
\hline & Vernagtbach & Rofenache & $\begin{array}{l}\text { Venter } \\
\text { Ache }\end{array}$ & \\
\hline Highest elevation (m a.s.l.) & 3633 & 3770 & 3770 & 2713 \\
\hline $\begin{array}{l}\text { Elevation with the most signifi- } \\
\text { cant area fraction (m a.s.l.) }\end{array}$ & 3125 & 3100 & 3100 & 1300 \\
\hline Lowest elevation (m a.s.l.) & 2635 & 1904 & 1877 & 700 \\
\hline Basin area $\left(\mathrm{km}^{2}\right)$ & 11.44 & 98.2 & 164.7 & 41.0 \\
\hline Percentage of glaciation $(\%)$ & 79 & 41 & 38 & 0 \\
\hline
\end{tabular}

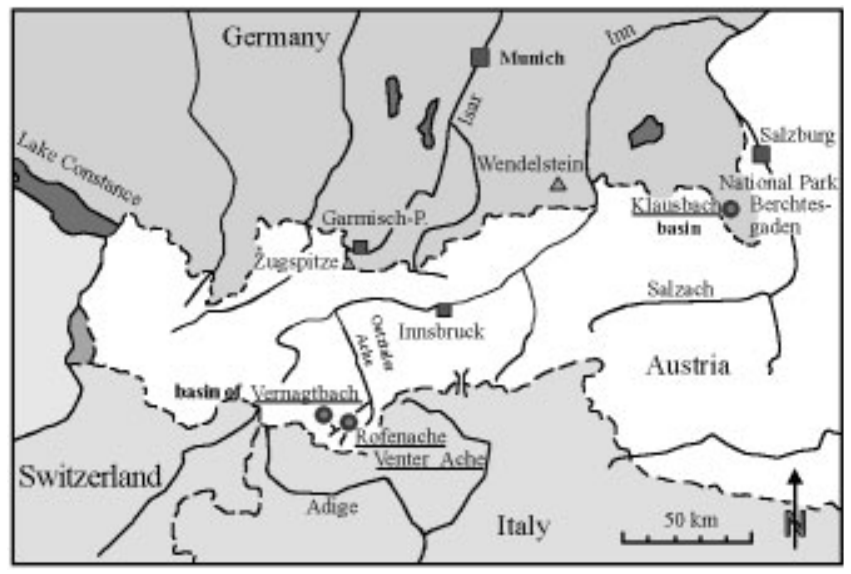

Fig. 4. Location map of the investigated basins.

ameters as determined over calibration periods also yielded good runoff modelling performance during the validation periods. For example, the mean Nash and Sutcliffe (1970) efficiency criterion $R^{2}$ is $0.87-0.93$ for the three glacierized basins given in Table 1 during the calibration period ( 6 years), as compared to $0.86-0.90$ for the verification period (13 or 15 years). A value of $R^{2}=1.0$ denotes a perfect fit between measured and simulated discharge. Independent testing of the intermediate results of snow storage and glacier mass balance adequately confirms that the model can be used for a realistic determination of all water-balance components under present-day conditions. The procedure described in step I leads to a kernel version of the HBV3-ETH9 model with a fixed set of parameters for each basin. This kernel is being used for further sensitivity studies of the hydrological system in respect to variations in the boundary conditions.

In a second step, results of climate modelling at the regional scale are used to investigate the impact of climate change on runoff. As already mentioned, runoff behaviour is to a large extent controlled by short-term weather. This cannot, however, be predicted using climate models, though operational weather-forecast models are able to do this for up to 10 days at most. Regional climate models MM5/MCGM (Grell and others, 1998) and REWIH3D (Fuentes and Heimann, 2000) of the BayFORKLIM modelling groups were able to provide statistical characteristics of weather patterns of a future climate under the assumption of a doubling of $\mathrm{CO}_{2}$. These characteristics include the frequency of days with maximum temperature above $30^{\circ} \mathrm{C}$ ("hot days"), or the frequency of days with significant convective precipitation (e.g. events greater than $1 \mathrm{~mm} \mathrm{~h}^{-1}$ ). This kind of information was used to adapt the meteorological data of a selected hydrological reference year as follows:

(a) during the spring and fall months, air temperature was increased only slightly by adding some days with higher air temperature, and a few precipitation events were added to the original time series;

(b) during the winter months, daily air temperature was increased by about $1 \mathrm{~K}$, and a few sporadic snowfall events were added, but the total precipitation amount was increased only slightly by about $5 \%$;

(c) during the summer months, additional "hot days" were introduced, with the result that in these months the mean monthly temperature was increased by about 
Table 2. Annual water-balance components $\left(\mathrm{mm} \mathrm{a}^{-1}\right)$ of the investigated glacierized basins as determined by the HBV3-ETH9 runoff model over the verification period

\begin{tabular}{|c|c|c|c|c|c|c|c|}
\hline Basin & $\begin{array}{c}\text { Discharge } \\
Q\end{array}$ & $\begin{array}{c}\text { Precipitation } \\
P\end{array}$ & $\begin{array}{c}\text { Evaporation } \\
E\end{array}$ & $\begin{array}{c}\text { Mass balance of glaciers } \\
\Delta S \text { glacier }\end{array}$ & $\begin{array}{c}\text { Snow storage } \\
\Delta S \text { snow }\end{array}$ & $\begin{array}{l}\text { Soil and ground-water storage } \\
\qquad \Delta S \text { ground }\end{array}$ & Period \\
\hline Rofenache & 1393 & 1322 & 189 & -301 & 45 & -4 & 1982/83-95/96 \\
\hline Venter Ache & 1332 & 1345 & 248 & -287 & 52 & 0 & $1980 / 81-95 / 96$ \\
\hline Klausbach & 1338 & 1926 & 588 & 0 & 0 & 0 & $1982 / 83-92 / 93$ \\
\hline
\end{tabular}

$5 \mathrm{~K}$; individual convective precipitation events were added during what originally were dry spells.

For the climate-modelling studies the 1970 s were used as a reference period. This period is characterized by rather cool and wet summers compared to present-day conditions. For the Rofenache basin, the hydrological year 1977/78 was chosen as reference year from the available data. The Berchtesgaden data of the 1970s were incomplete, so the hydrological year 1986/87 was chosen instead, showing the closest similarity to 1977/78. The meteorological data were adapted as described above to express the above-mentioned climatic change, and discharge was recalculated (step II in Fig. 3).

The modified climate as used in this simulation is expected under the condition of a doubled concentration of $\mathrm{CO}_{2}$, occurring in approximately 50 years given the predicted emission rates. The transition period is not treated, so the simulation run assuming a glacier extent as of 1990 is an extreme case. More realistically, glacier extent will be reduced as investigated in a third step (step III in Fig. 3). In future modelling attempts, the simulation of glacier mass balance needs to be employed to allow inferences on the time of the disappearance of glaciers in a given catchment and the chosen climate scenario, and hence yield a timeframe in which the discharge scenarios as presented will eventually become a reality.

\section{RESULTS}

\section{Simulations under present-day conditions: annual water balance}

Table 2 summarizes the results of the simulated components of the water balance of the investigated basins under present-day conditions. Over the 13-15 years considered in the

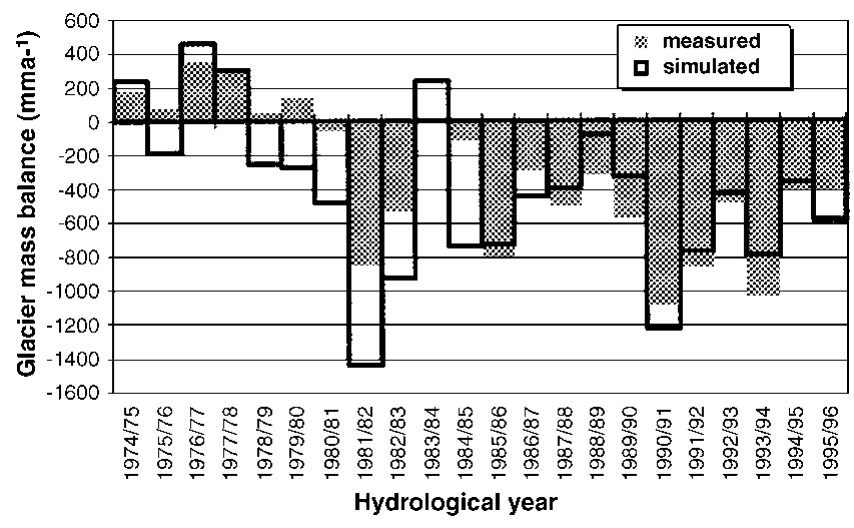

Fig. 5. Comparison between measured and simulated annual glacier mass balance, Vernagtferner, 1974-95. glacierized basins, the storage changes of the glaciers are strongly negative, which reflects the general excess melting of glacier ice since the early 1980s. The approximately $50 \mathrm{~mm}$ of snow storage carried over from one hydrological year to the next is concentrated on the uppermost parts of high-Alpine basins as shown in Table 1, which are areas located above the mean zero degree level.

In the conceptual model used here, redistribution of mass input is treated only by the melt process using a temperature index method. All other dynamic processes leading to a redistribution of mass from higher to lower elevations, in particular redistribution of snow by wind drift and avalanches, or ice flow, are not considered. The importance of these processes within the considered period is reflected by the abovementioned mean snow-storage value, which is approximately $3 \%$ of basin precipitation. In contrast to the glacierized basins, the Klausbach basin is well below the mean altitude of the zero degree level, so melting indexed only by air temperature is sufficient to achieve the expected value of zero snow storage at the end of the hydrological year. For the evaluation of climate-change impact as presented in this study it is not necessary to take explicitly into account this problem occurring in glacierized basins, because this model inaccuracy is well within the general error margin, and is indeed expected to be smaller in a warmer climate.

The values of evaporation given in Table 2 range from $12 \%$ of basin precipitation in the Vernagtbach catchment to $18 \%$ in the Venter Ache, and up to $30 \%$ in the Klausbach catchment. The values in the high-Alpine basins are rather low compared to those in lowland regions, where basin evaporation values of up to $600 \mathrm{~mm}$ (or approximately $50 \%$ of basin precipitation) are observed (Gurtz and others, 1999). This confirms the minor role of the evaporation component in the water balance of highAlpine regions (Lang, 1981), even under a changed climate.

\section{Simulation under present-day conditions: glacier mass balance}

It was possible to test the intermediate results of simulated glacier mass as part of the application of the HBV3-ETH9 runoff model on the Vernagtbach basin, as measured values of the mass balance since 1964/65 of Vernagtferner are available (Reinwarth and Escher-Vetter, 1999). They were determined by the direct glaciological method using the fixeddate system (1 October to 30 September the following year). Figure 5 shows the year-to-year variation in measured and simulated mass balance over 22 years, and one can observe that the general pattern is reproduced (explained variance $68 \%)$. There is a tendency to underestimate the mass balance, in particular in the years prior to $1985 / 86$, with the result that the modelled sum over all 22 years is $-9211 \mathrm{~mm}$, 


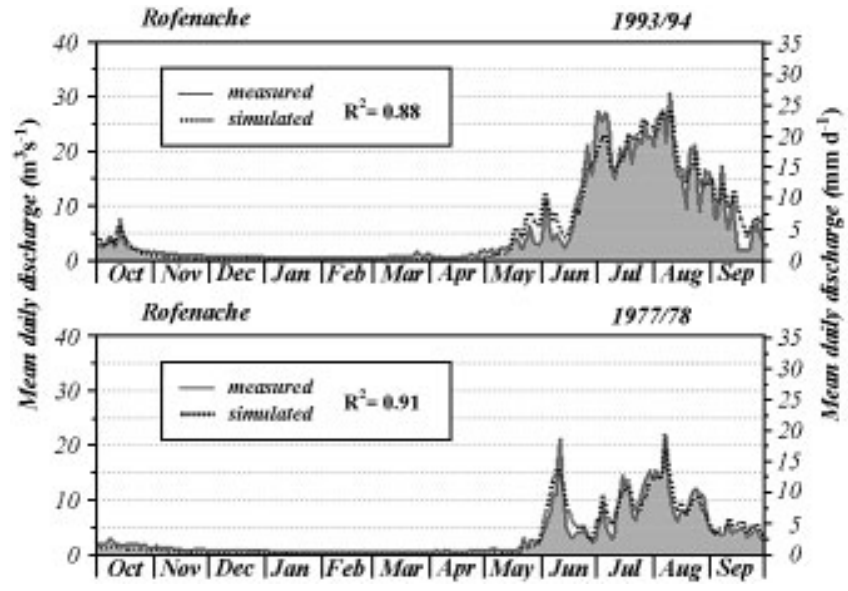

Fig. 6. Comparison between measured and simulated daily discharge of the Rofenache basin for two years of strongly differing glacier mass balance.

underestimating the measured value of $-7159 \mathrm{~mm}$ by $29 \%$. However, as mentioned at the beginning of this section, redistribution of mass, in particular by ice flow, is not considered in the model used here. The deviation between modelled and observed values can be attributed in part to the omission of this efficient transport process.

\section{Simulations under present-day conditions: discharge}

Figure 6 illustrates the ability of the HBV3-ETH9 model to simulate a wide variety of runoff conditions. Here, daily means of measured and calculated discharge of the Rofenache are given for the hydrological years 1977/78 (positive glacier mass balance) and 1993/94 (strongly negative glacier mass balance). In 1977/78 observed annual discharge was $1005 \mathrm{~mm}$, and measured mass balance of the Vernagtferner was $+288 \mathrm{~mm}$, whereas in 1993/94 discharge amounted to $1799 \mathrm{~mm}$ with a mass balance of $1028 \mathrm{~mm}$ for the Vernagtferner. Over the total verification period (13-15 years) simulated discharge is underestimated by $4.6 \%, 7.5 \%$ and $7.6 \%$ in the Vernagtbach, Venter Ache and Rofenache basins, respectively.

\section{Influence of the climate change scenario $2 \times \mathrm{CO}_{2}$ on discharge}

The non-glacierized Klausbach basin (Table 1; Fig. 4) is situated on the northern fringe of the Alps in the Berchtesgaden National Park. Here, the meteorological input data of the reference year 1986/87, characterized by an above-normal snowpack, were altered in accordance with the results of the regional climate model (MM5/MCGM), and the impact of the changes on snow storage and discharge was evaluated. When comparing the reference run with the scenario run, maximum snow accumulation at $2500 \mathrm{~m}$ a.s.l. was reduced from $1030 \mathrm{~mm}$ to $930 \mathrm{~mm}$ w.e. (reduction by about $10 \%$ ), and at $1300 \mathrm{~m}$ a.s.l. with the maximum area fraction this reduction was from $450 \mathrm{~mm}$ to $350 \mathrm{~mm}$ w.e. (i.e. about $22 \%$ ). The snow cover at this elevation disappeared on 20 April, about 10 days earlier than in the reference run using present-day conditions. Looking at the consequences for discharge (Fig. 7), no major change of the hydrograph pattern resulted due to this scenario. Increased runoff peaks due to enhanced snowmelt events can be dis-

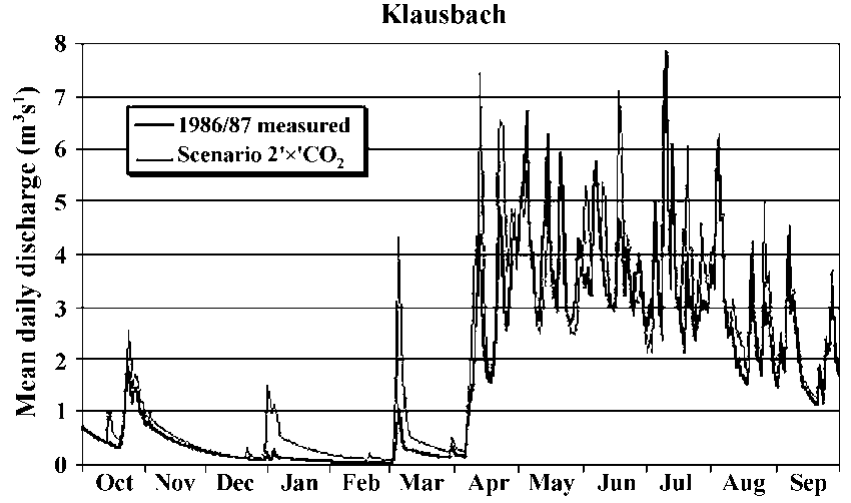

Fig. 7. Effect of adapted input data (scenario $2 \times \mathrm{CO}_{2}$ ) on daily mean discharge of Klausbach, compared to the reference run 1986/87.

cerned during winter and early spring, but at the time of substantial temperature increase in summer the snowmelt season is already over, and increased flood peaks are due to the additional convective rainfall events as predicted by the scenario. This situation is typical for lower Alpine regions, as it shows that the hydrological systems here react primarily to changes in precipitation rather than to rising summer temperatures.

In basins reaching into higher elevations, the runoff processes are more strongly affected by the assumed climatic change. With increasing summer temperature the number of days with positive air temperature increases, and the snowfall fraction of total precipitation decreases. Contrary to the Klausbach case, where the climate modification shows only a slight change in the ratio between solid and liquid precipitation, this ratio is reduced from 2 to 1 in the high-Alpine Rofenache case. As a result, snow storage is markedly reduced and its influence on runoff production significantly changed.

1. Glacierization 1990

Bofenache
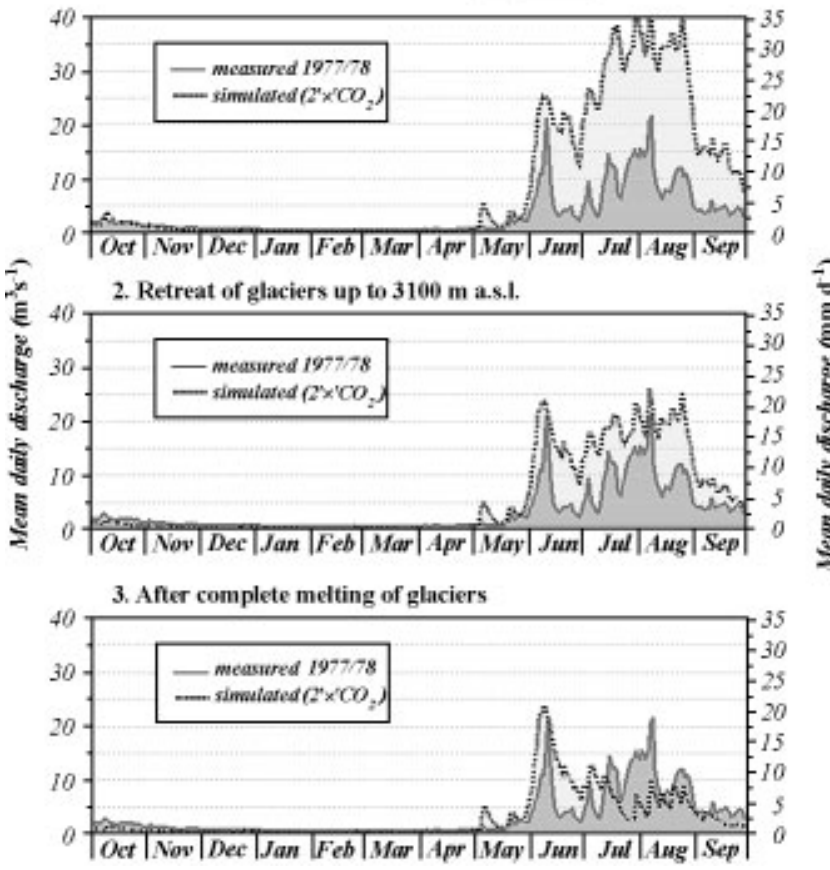

Fig. 8. Effect of an assumed climatic change and deglacierization on discharge of Rofenache. 
In high-Alpine basins substantial areas are still glacierized; in the case of the Rofenache, this area fraction is $40 \%$ (Table 1). These areas react most sensitively to increased air temperatures and produce the highest additional water yield. The effect of modified input data is discussed for the Rofenache on the basis of the hydrological year 1977/78, showing rather low discharge in the reference case (Fig. 6), dominated by substantial snowmelt in June and low runoff due to only moderate ice melt and rain in the remaining summer months. In the climate scenario case (Fig. 8) with 1990 glacierization, mean daily discharge is most significantly increased in July and August to $35 \mathrm{mmd}^{-1}$ or $40 \mathrm{~m}^{3} \mathrm{~s}^{-1}$, amounts which have not been observed to date. However, a remarkable similarity with the discharge of 1993/94 (Fig. 6) can be discerned. Increased water yield is mainly due to increased ice melt; the contribution from snowmelt is hardly changed.

In the case of prolonged substantial ice losses, the glacierized area will be markedly reduced; in the example of the Rofenache basin, glaciers would recede to areas above approximately $3100 \mathrm{~m}$ a.s.l. within some 30 years. This scenario of deglacierization is assumed in the simulation of discharge in Figure 8b, with the effect of a substantial reduction of water yield from the glaciers to levels of discharge similar to those observed at present.

If the glaciers in the Oetztal Alps should disappear completely, say at the end of the 21st century, water yield would be drastically reduced, as shown in Figure 8c. Substantial runoff is observed only during the snowmelt phase, and the runoff regime will be similar to the present-day nivo-pluvial regime in the lower-Alpine regions.

\section{SUMMARY AND CONCLUSIONS}

Short-term weather most significantly affects runoff generation against the background of the state of storage controlled by long-term climate conditions (Fig. 1). The regional climate model MM5/MCCM, for example, cannot provide the shortterm weather forecasts needed, but can predict some characteristics of climate change on the regional scale: a rise in the climatic snowline, more frequent hot summer days and additional convective precipitation events. Based on a scenario of doubling the atmospheric $\mathrm{CO}_{2}$ concentration, the effect on runoff is investigated using a conceptual precipitation-runoff model (HBV-ETH9) in connection with input data specifically adapted to correspond to the predicted changes. However, hydrological and physiographical characteristics of the catchments were assumed not to be influenced by climate change. The method was applied in selected basins located in the Bavarian and central Alps, showing nivo-pluvial and glacial runoff regimes, respectively. The results show that the hydrological systems of the Bavarian Alps, a region with insignificant glacierization, react primarily to changes in precipitation, rather than to rising mean summer temperatures. In highly glacierized catchments, however, the same scenarios suggest enhanced water yields in an initial phase. If glacier mass losses continue in the more distant future, the glacierized area will diminish and summer discharge will be gradually reduced, resulting in drastic water shortages in hot, dry summers once the glaciers have disappeared.

The conceptual modelling approach as presented here is well suited to determine the water-balance components and, in particular, runoff from Alpine regions. Due to the rather modest data-input requirements (daily mean air temperatures, daily sums of precipitation, degree of glacierization) simulations are possible under any climatic conditions and extent of glacierization. Numerous applications over a wide variety of regions (e.g. the Nepalese Himalaya, as shown in Braun and others, 1998) confirm that simulation results are realistic if the input data are correct.

Despite the great research efforts in climate modelling, there is no certainty concerning climate development in the future. The majority of the scientific community favour the scenario used in this study, but opinions differ. This study suggests that glacierized parts of the Alps and their downstream areas are more affected by global warming than the head watersheds of the Bavarian Alps, for example, which are devoid of substantial glaciers. The most frequent cause for floods in Alpine basins is prolonged and intensive rainfall combined with late snowmelt following high snow accumulation during winter. The probability of such events is not necessarily affected by global warming. The HBV3-ETH9 model is, however, capable of predicting the magnitude of such floods in conditions of extreme snow accumulation given probable short-term temperature and precipitation forecasts.

In highly glacierized basins global warming will definitely cause increased runoff yield in an initial phase, which has been observed before in years with negative glacier mass balances (Kasser, 1960; Escher-Vetter and Reinwarth, 1995). Especially in years after an uninterrupted sequence of strongly negative mass balances such as the period 1985-98, an ever-increasing extension of the bare-ice areas on glaciers at the cost of firn areas is observed, resulting additionally in a marked increase in diurnal variations in runoff (Braun and Escher-Vetter, 1996; Reinwarth and Braun, 1998). Under the assumption of global warming, this tendency will continue, leading to a disposition to flooding, especially when high ice-melt rates and more frequent thunder-showers coincide.

\section{AGKNOWLEDGEMENTS}

Financial support was provided by the Bavarian Climate Research Programme (BayFORKLIM). Data were made available by the Meteorological and Hydrological Services of Austria and Germany, the Tyrolean Hydropower Corporation (TIWAG), the Institute of Meteorology and Geophysics at the University of Innsbruck, and the Administration of the Berchtesgaden National Park. W. Rott, Innsbruck, and R. Würländer, Munich, assisted in determining the glacierized area. H. Escher-Vetter, O. Reinwarth, S. Braun-Clarke and L. Soturczak made valuable comments on the text. All these contributions are gratefully acknowledged.

\section{REFERENCES}

Bergström, S. 1992. The HBV model - its structure and applications. Norrköping, Sweden, Sveriges Meteorologiska och Hydrologiska Institut. (SMHI Report RH 4.)

Braun, L. N. and H. Escher-Vetter. 1996. Glacial discharge as affected by climate change. In Interpraevent 1996: Protection of Habitat against Floods, Debris Flows and Avalanches, 24-28 June 1996, Garmisch-Partenkirchen, Germany. München, Bayerisches Landesamt für Wasserwirtschaft, 65-74. (Tagungspubl. 1.)

Braun, L. N., Ch. Hottelet, M. Weber and W. Grabs. 1998. Measurement and simulation of runoff from Nepalese head watersheds. International Association of Hydrological Sciences Publication 248 (Symposium at Meran/Merano 1998 - Hydrology, Water Resources and Ecology in Headwaters), 9-18.

Ehrler, C. 1998. Klimaänderung und alpine Schneedecke. Auswirkungen auf das Abflussregime am Beispiel des Einzugsgebiets Rhein-Felsberg. Zürich, vdf 
Hochschulverlag AG. ETH Zürich. (Projektschlussbericht im Rahmen des Nationalen Forschungsprogrammes "Klimaänderungen und Naturkatastrophen".)

Escher-Vetter, H. and O. Reinwarth. 1995. Two decades of runoff measurements (1974 to 1993) at the Pegelstation Vernagtbach/Oetztal Alps. Z Gletscherkd. Glazialgeol., 30, 1994, 53-98.

Escher-Vetter, H., M. Weber and L. N. Braun. 1998. Auswirkungen von Klimaänderungen auf den Wasserhaushalt alpiner, teilweise vergletscherter Gebiete. In Klimaerwärmung Gletscher - Wie verändern sich die Gebirgsabflüsse. München, Bayerische Akademie der Wissenschaften. Kommission für Glaziologie, CD-ROM. (Schlussbericht BayFORKLIM.)

Fuentes, U. and D. Heimann. 2000. An improved statistical-dynamical downscaling scheme and its application to the Alpine precipitation climatology. Theor. Appl. Climatol., 65, 119-135.

Grell, G., L. Schade, R. Knoche and A. Pfeiffer. 1998. Regionale Klimamodellierung. München, Universität München. Meteorologisches Institut. Wissenschaftliches Sekretariat. (Schlussbericht BayFORKLIM.)

Gurtz, J., A. Baltensweiler, H. Lang, L. Menzel and J. Schulla. 1997. Auswirkungen von klimatischen Variationen auf Wasserhaushalt und Abfluss im Flussgebiet des Rheins. Zürich, vdf Hochschulverlag AG. ETH Zürich. (Schlussbericht NFP 31.)

Gurtz, J., A. Baltensweiler and H. Lang. 1999. Spatially distributed hydrotope-based modelling of evapotranspiration and runoff in mountainous basins. Hydrol. Processes, 13, 2751-2768.
Kasser, P. 1960. Über die Gletscheränderungen seit 1900 in den Schweizer Alpen mit Hinweisen auf die Bedeutung für die Wasserwirtschaft. Wasserund Energiewirtschaft, $1960(8-10), 1-11$.

Kuhn, M. and N. Batlogg. 1998. Glacier runoff in Alpine headwaters in a changing climate. International Association of Hydrological Sciences Publication 248 (Symposium at Meran/Merano 1998 - Hydrology, Water Resources and Ecology in Headwaters), 79-88.

Kuhn, M. and N. Batlogg. 1999. Modellierung der Auswirkung von Klimaänderungen auf verschiedene Einzugsgebiete in Österreich. Vienna, Österreichische Elektrizitätswirtschaft-Aktiengesellschaft. (Schriftenreihe Forschung im Verbund 46.)

Kwadijk, J. 1993. The impact of climate change on the discharge of the Rhine River. Utrecht, Universiteit Utrecht. (Nederlandse Geografische Studies.)

Lang, H. 1981. Is evaporation an important component in high alpine hydrology? Nord. Hydrol., 12, 217-224.

Nash, J. E. and J.V. Sutcliffe. 1970. River flow forecasting through conceptual models. Part 1. A discussion of principles. 7. Hydrol., 10 (3), 282-290.

Reinwarth, O. and L. N. Braun. 1998. Structural adaptation of a high alpine gauging station (Vernagtbach, Oetztal Alps/Austria) to greatly enhanced glacial discharge. In Proceedings of the International Conference on Ecohydrology of High Mountain Areas, Kathmandu, 23-28 March 1996. Kathmandu, International Centre for Integrated Mountain Development (ICIMOD), 199-205.

Reinwarth, O. and H. Escher-Vetter. 1999. Mass balance of Vernagtferner, Austria, from 1964/65 to 1996/97: results for three sections and the entire glacier. Geogr. Ann., 81A(4), 743-751. 